\title{
EFEKTIVITAS PERMAINAN FLOWER CIRCUIT TERHADAP PERKEMBANGAN FISIK MOTORIK KASAR ANAK USIA 5-6 TAHUN DI TRENGGALEK
}

\author{
Anggi Eka Haryanti ${ }^{1}$, Usep Kustiawan ${ }^{2}$, Retno Tri Wulandari ${ }^{3}$ \\ Universitas Negeri Malang \\ E-mail:anggieka0903@gmail.com No. HP 085219345006
}

\begin{abstract}
The purpose of this study was to determine the effectiveness of flower circuit games on the development of gross physical motor of group B children. The scope of this study was about gross motor skills that included elements of physical fitness such as strength, accuracy, agility and balance. This study uses a quantitative approach with the specifications of the study using quasi experiment research methods. Data from quantitative research results in the form of numerical values obtained from the calculation of the results of the pretest and posttest scores. The results of the calculation of pretest and posttest can be concluded that the flower circuit game is effective againts the development of gross motoric physicality of children in RA Al Huda Rejowinangun Trenggalek.
\end{abstract}

Keywords: Effectiveness; Game Flower circuit; gross motoric abilities.

\begin{abstract}
Abstrak: Tujuan penelitian ini adalah mengetahui efektivitas permainan flower circuit pada pembelajaran fisik motorik kasar anak kelompok B. Ruang lingkup penelitian ini mengenai kemampuan motorik kasar yang mencakup unsur-unsur kebugaran jasmani seperti kekuatan, ketepatan, kelincahan dan keseimbangan. Penelitian ini menggunakan pendekatan kuantitatif dengan spesifikasi penelitian menggunakan metode penelitian quasi experiment (eksperimen semu). Data hasil penelitian kuantitatif berupa nilai angka yang diperoleh dari hasil perhitungan skor hasil pretest dan posttest. Hasil perhitungan pretest dan posttest dapat disimpulkan bahwa permainan flower circuit efektif terhadap perkembangan fisik motorik kasar anak kelompok B di RA Al Huda Rejowinangun Trenggalek.
\end{abstract}

Kata kunci: Efektivitas; Permainan Flower circuit; kemampuan fisik motorik kasar.

Pada masa usia dini, anak berada dalam proses perkembangan yang unik. Pada masa ini, proses tumbuh dan kembang anak terjadi bersama dengan golden age (masa peka), yaitu masa yang paling tepat untuk memberikan bekal yang kuat kepada anak. Pada masa ini, perkembangan otak anak berkembang dengan pesat, sehingga merupakan masa yang sangat tepat untuk menggali segala potensi kecerdasan anak. Cara yang dapat dilakukan oleh pendidik adalah dengan memberikan stimulasi melalui berbagai aktivitas permainan. 
Pemberian stimulus yang baik merupakan cara membantu anak untuk dapat mencapai aspek-aspek perkembangan dengan baik pula. Stimulus dapat diperoleh anak melalui kegiatan belajar sambil bermain pada pendidikan anak usia dini. Pendidikan Anak Usia Dini (PAUD) merupakan suatu upaya pembinaan yang ditujukan kepada anak sejak lahir hingga usia enam tahun yang dilakukan melalui pemberian rangsangan pendidikan untuk membantu pertumbuhan dan perkembangan jasmani dan rohani agar anak memilikai kesiapan belajar guna memasuki pendidikan lanjut.

Pertumbuhan dan perkembangan jasmani berkaitan dengan perkembangan fisik motorik anak. Hurlock (1978:159) mengartikan bahwa perkembangan motorik diartikan sebagai perkembangan dari unsur kematangan pengendalian gerak tubuh dan otak sebagai pusat gerak. Melalui karakteristik unik anak yaitu keingintahuan yang besar dan keinginan anak untuk mencoba, anak dapat melakukan latihan-latihan fisik motorik melalui gerakan-gerakan terkoordinasi yang difasilitasi dengan lingkungan yang mendukung atas pemberian stimulasi tersebut. Sesuai dengan yang dipaparkan oleh Rahyubi (2012:228), lingkungan yang mendukung anak untuk bergerak bebas dapat mengoptimalkan perkembangan motorik pada anak usia dini. Aktivitas di luar ruangan dapat menjadi alternatif terbaik karena dapat menstimulasi perkembangan otot dengan berlari, melompat, dan menggerakkan seluruh tubuhnya.

Kemampuan fisik motorik anak penting dikembangkan sejak usia dini, karena selain mempengaruhi kondisi kesehatan badannya, stimulasi fisik motorik yang optimal akan membuat anak lebih percaya diri dan mandiri. Anak yang mengetahui kemampuan fisiknya, akan merasa yakin saat mengerjakan beragam aktivitas. Anak juga dapat mengimbangi gerakan temantemannya ketika perkembangan fisik motoriknya optimal. Anak juga akan lebih mudah berkreasi sesuai dengan keinginannya sendiri ketika perkembangan fisik motoriknya berkembang optimal.

Berdasarkan studi pendahuluan melalui kegiatan observasi di kelompok B RA Al Huda Rejowinangun, ditemukan kendala dalam pembelajaran fisik motorik anak. Hasil observasi menunjukkan bahwa 10 dari 24 anak yang ada pada kelompok B RA Al Huda Rejowinangun belum mengikuti kegiatan pembelajaran fisik motorik dengan baik. Hal ini disebabkan karena anak kurang tertarik pada kegiatan yang disajikan guru yang terlalu monoton dan diulang-ulang, yaitu senam dan aktifitas peregangan otot. Ketidaktertarikan anak pada kegiatan pembelajaran fisik motorik ditandai dengan anak hanya asal-asalan menirukan gerakan guru, anak hanya berdiri dan diam, anak sering bergurau sendiri dengan temannya.

Berdasarkan latar belakang yang diuraikan di atas, peneliti ingin memberikan stimulus baru melalui sebuah permainan. Kegiatan permainan yang dikemas dengan menarik akan membuat anak-anak senang mengikuti kegiatan pembelajaran, sehingga fisik motorik anak dapat dioptimalkan. Penerapan permainan ini diadopsi dari penelitian Kharisma (2015) dengan judul 
"Pengembangan Permainan Flower Circuit Pada Pembelajaran Fisik Motorik Kasar Untuk Anak Kelompok B Di Taman Kanak-Kanak Kecamatan Gudo-Jombang”. Flower Circuit merupakan permainan yang terdiri dari beberapa pos dan mempunyai kegiatan yang berbeda-beda pada setiap pos. Kegiatan-kegiatan pada setiap pos harus dilakukan anak secara bertahap.

\section{METODE}

Penelitia ini menggunaan pendekatan kuantutatif dengan spesifikasi penelian menggunakan metode penelitian quasi exsperiment (ekasperimen semu) yang bertujuan untuk mengetahui hubungan sebab akubat antara dua faktor yang ditimbulkan dalam penelitian. Penelitian ini menggunakan desain kelompok tunggal dengan prestest dan postest. Subjek dalam penelitian ini mendapatka perlakuan (treatment) yang berupa permainan Flower Circuit. Peneliti akan memberikan pretest (O1) terlebih dahulu sebelum anak mendapatkan perlakuan dan sebagai kegiatan pengukuran awal. Kemudian akan diberikan perlakuan berupan permainan Flower Circuit, setelah itu akan dilakukan pengukuran kembali setelah pemberian perlakuan yang disebut posttest (O2). Waktu penelitian ini dilakukan pada tanggal 27 April-11 Mei 2019 di RA Al Huda Rejowinangun Trenggalek.

Penelitian ini menggunakan populasi 1 kelas kelompok B di RA Al Huda Rejowinangun Trenggalek yang berjumlah 24 anak. Jumlah populasi dan sampel pada penelitian ini sama. Populasi yang digunakan dalam penelitian ini berjumlah kurang dari 30 anak sehingga digunakan populasi total untuk dijadikan sampel penelitian yaitu sejumlah 24 anak dengan rincian 10 anak laki-laki dan 14 anak perempuan. Subjek penelitian yang terkait dalam pengambilan data untuk penelitian dan pengembangan ini adalah sebagai berikut: (1) Penelitian awal dan pengumpulan informasi dilakukan dengan cara observasi awal terkait kegiatan-kegiatan fisik motorik kasar yang terdapat di RA Al Huda Rejowinangun Trenggalek; (2) Subjek validasi instrumen terdiri dari dua ahli instrumen (3) Subjek pengujian pretest dan posttest 1 kelas kelompok B di RA Al Huda Rejowinangun Trenggalek yang berjumlah 24 anak.

Teknik pengumpulan data yang digunakan dalam penelitian ini adalah teknik observasi dan dokumentasi. Instrumen pengumpul data yang digunakan dalam penelitian ini adalah lembar observasi dalam bentuk skala rating (rating scale). Proses aktivitas anak dibuat dalam bentuk daftar penilaian yang sudah dikelompokkan berdasarkan aspek yang akan dinilai sesuai dengan indikator. Penilaian dalam penelitian ini dilakukan dengan menggunakan rubrik yang memuat indikator dan kriteria dengan skor 1-4 pada masing-masing indikatornya. Data yang dikumpulkan menggunakan lembar observasi merupakan data dari subjek penelitian pada pretests dan posttest mengenai aktivitas motorik kasar anak kelompok B. Dilakukan uji validitas terhadap instrumen berupa uji validitas konstruk yang didasarkan pada pendapat ahli dan juga uji reliabilitas 
menggunakan Alpha pada aplikasi SPSS. Instrumen pengumpul data dari teknik dokumentasi berupa foto kegiatan uji coba dan rencana pembelajaran menggunakan sircuit flower.

Teknik analisis data yang digunakan pada penelitian ini adalah analisis statistik inferensial. Analisis data dilakukan menggunakan uji t untuk mencari persamaan dan perbedaan variabel yang ada setelah diberikan perlakuan. Uji-t berfungsi untuk mengetahui efektivitas permainan flower circuit terhadap kemampuan fisik motorik kasar anak kelompok B dalam penelitian ini. Uji-t dilakukan menggunakan aplikasi SPSS.

Skor rata-rata selisih antara variabel 1 dan variabel 2 akan diperoleh setelah dilakukan analisis menggunakan SPSS. Selain itu juga akan diperoleh data standard errornya. Pemberian makna dan pengambilan keputusan terhadap nilai t yang diperoleh, dapat menggunakan dasar acuan yang dijelaskan dalam Sugiyono (2016:147), jika nilai $t$ hitang $\geq t$ tabel maka ho ditolak. Jika nilai $\mathrm{t}$ hitung $\leq \mathrm{t}$ tabel maka ho ditolak.

\section{HASIL}

Pelaksanaan pretest dilakukan peneliti pada tanggal 27 April 2019. Pretest dilakukan dengan cara peneliti memberikan penilainan terhadap aspek kekuatan, ketepatan, kelincahan, dan keseimbangan pada masing-masing anak. Kegiatan yang diterapkan pada pretest adalah kegiatan sekolah yang biasa dilakukan anak pada kegiatan fisik motorik kasar sehari hari di RA Al Huda Rejowinangun yang memiliki unsur kekuatan, ketepatan kelincahan dan keseimbangan.

Pada pretest ini jumlah anak yang mendapatkan skor rendah 2 anak, yang mendapat skor sedang 12 anak dan yang medapat skor tinggi 10 anak. Hasil tersebut menunjukkan bahwa kemampuan fisik motorik kasar anak di RA Al Huda Rejowinangun Trenggalek sudah berkembang dengan cukup baik.

Setelah memperoleh data pretest peneliti mencari nilai rata-rata, nilai maksimum, nilai minimum dan standart Deviasi pada kelompok B1. Berikut ini adalah data hasil dari perhitungan yang dilakukan oleh peneliti.

Tabel 1.1 Nilai Rata-Rata, Nilai Maksimum, Nilai Minimum dan Standart Deviasi Pretest

\begin{tabular}{lllll}
\hline Kelas & Rata rata & Maksimum & Minimum & Standart Deviasi \\
\hline B1 & $\mathbf{1 1 , 2 0 8 3}$ & $\mathbf{1 4 . 0 0}$ & $\mathbf{5 . 0 0}$ & $\mathbf{2 . 3 9 5 2 7}$ \\
\hline
\end{tabular}

Berdasarkan tabel 1.1 diatas nilai rata-rata yang diperoleh kelas B1 RA Al Huda Rejowinangun Trenggalek sebesar 11,2083. Nilai maksimum sebesar 14.00 sedangkan nilai minimumnya sebesar 5.00. nilai standart deviasi yang dihasilkan di kelas B1 RA Al Huda Rejowinangun Trenggalek sebesar 2.39527. 
Pelaksanaan posttest dilakukan peneliti pada tanggal 11 Mei 2019. Pretest dilakukan dengan cara peneliti memberikan penilainan terhadap aspek kekuatan, ketepatan, kelincahan, dan keseimbangan pada masing-masing anak. Kegiatan yang diterapkan pada posttest adalah kegiatan sekolah yang biasa dilakukan anak pada kegiatan fisik motorik kasar sehari hari di RA Al Huda rejowinangun yang memiliki unsur kekuatan, ketepatan kelincahan dan keseimbangan. Kegiatan posttest ini merupakan kegiatan yang sama dengan kegiatan pretest. Hal ini dimaksudkan untuk mengetahui perbedaan kemampuan fisik motorik kasar anak pada saat pretest dan posttest.

Pada posttest ini terdapat 2 anak yang mendapat skor sedang dan 22 anak medapat skor tinggi. Hasil tersebut menunjukkan bahwa kemampuan fisik motorik kasar anak di RA Al Huda Rejowinangun Trenggalek sudah berkembang dengan sangat baik. Peneliti selanjutnya mencari nilai rata-rata, nilai maksimum, nilai minimum dan standart Deviasi pada kelompok B1. Berikut ini adalah data hasil dari perhitungan yang dilakukan oleh peneliti.

Tabel 1.2 Nilai Rata-Rata, Nilai Maksimum, Nilai Minimum dan Standart Deviasi Posttest

\begin{tabular}{lllll}
\hline Kelas & Rata rata & Maksimum & Minimum & Standart Deviasi \\
\hline B1 & 13.2083 & 16.00 & 10.00 & 2.10546 \\
\hline
\end{tabular}

Berdasarkan tabel 1.2 nilai rata-rata yang diperoleh kelas B1 RA Al Huda Rejowinangun Trenggalek sebesar 13.2083. Nilai maksimum sebesar 16.00 sedangkan nilai minimumnya sebesar 10.00. nilai standart deviasi yang dihasilkan di kelas B1 RA Al Huda Rejowinangun Trenggalek sebesar 2.10546 .

Mengacu pada data penelitian yang diperoleh, terdapat peningkatan antara sebelum diberika treatment melalui permainan Flower Circuit dan setelah diberikan treatment. Perbandingan hasil pretest dan posttest dapat dilihat melalui tabel 1.3 berikut :

Tabel 1.3 Perolehan skor Pretest dan Posttest

\begin{tabular}{lcccc}
\hline No. & Skor & Klarifikasi & Pre-test & Post-test \\
\hline 1. & $6-11$ & Rendah & 2 & 0 \\
\hline 2. & $12-17$ & Sedang & 12 & 2 \\
\hline 3. & $18-24$ & Tinggi & 10 & 22 \\
\hline
\end{tabular}

Berdasarkan Tabel 1.3 dapat disimpulkan bahwa terdapat penurunan jumlah anak antara pretest pada klasifikasi rendah yaitu sebanyak 1 anak, sedangkan pada posttest tidak ada yang masuk dalan klasifikasi rendah. Klasifikasi sedang menunjukkan pretest sebanyak12 anak turun setelah diberika treatment melalui permainan flower circuit menjadi 2 anak . pada klasifikasi tnggi menunjukkan hasil pretest sebanyak 10 anak meningkat setelah diberikan treatment melalui permainan flower circuit menjadi 22 anak. dengan demikian dapat disimpulkan bahwa terdapat 
peningkatan antara diberika treatment dan setelah diberikan treatment melalui permainan flower circuit.

\section{Gambar 1.1 Jumlah Data Pretest dan Posttest Kelompok B1 RA Al Huda Rejowinangun Trenggalek}

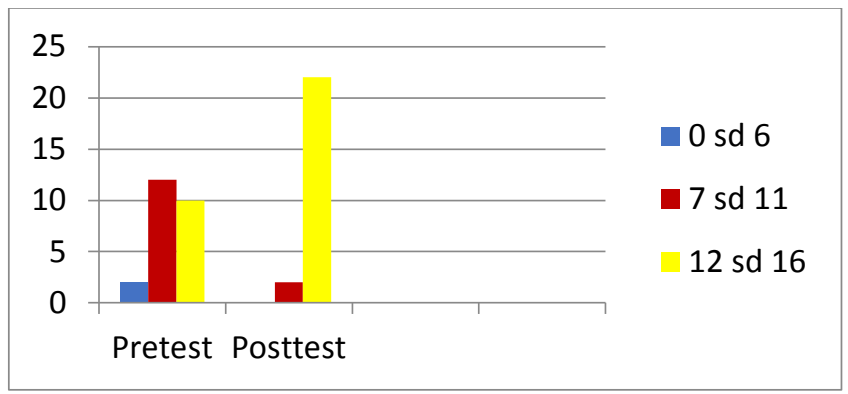

Keterangan :

0 sd $6 \quad$ : Skor Rendah

7 sd $11 \quad$ : Skor sedang

12 sd $16 \quad$ : Skor tinggi

Terdapat perbedaan antara skor sebelum diberikan treatment (pretest) dan skor setelah diberikan treatment (posttest). Perbedaan tersebut menunjukkan adanya peningkatan kemampuan motorik kasar setelah diberikan tretment berupa permainan flower circuit. terlihat hampir seluruh siswa mengalami peningkatan. Skor rata-rata antara pretest dan posttest sebesar 2. Berdasarkan data tersebut dapat disimpulkan bahwa pemberian treatmen berupa permainan flower circuit ini berpengaruh terhadap peningkatan perkembangan fisik motorik anak kelompok B RA Al Huda Rejowinangun Trenggalek.

\section{PEMBAHASAN}

Perkembangan Kemampuan Fisik Motorik Kasar Sebelum Penerapan Permainan Flower Circuit

Kemampuan fisik motorik kasar merupakan kemampuan yang berpengaruh pada aspek perkembangan anak yang lainnya karena berhubungan dengan kemampuan gerak. Setelah melakukan pretest di RA Al Huda Rejowinangun Trenggalek peneliti mendapatkan data kemampuan fisik motorik kasar yang dimiliki anak di satu kelas yang dijadikan sampel penelitian. Satu kelas ini adalah kelas B1 dengan jumlah 24 anak. Pada saat pretest peneliti menilai anak dari kegiatan sehari hari yang biasa dilakukan anak disekolah sebagai kegiatan pengembangan fisik motorik kasar anak dalam proses pembelajaran. Kegiatan yang diambil peneliti merupakan kegiatan yang mempuanyai unsur kebugaran kekuatan, ketepatan, kelicahan dan keseimbangan.

Berdasarkan data pretest kelas B1 RA Al Huda Rejowinangun memiliki rata-rata 11,2083. Data tersebut menunjukkan bahwa kemampuan fisik motorik yang dimiliki anak masih cukup 
berkembang. Anak dapat dikatakan berkembang dengan baik dalam aspek fisik motorik kasar apabila kemampuan yang dimilikinya sama dengan karakteristik perkembangan fisik motorik kasar anak usia 5-6 tahun yang dikemukakan oleh Sujiono (2007: 15-16) meliputi mampu berjalan jinjit, mampu meniti diatas papan, mampu menentukan pijakan, memiliki daya tahan dalam periode yang lebih lama dan lain sebagainya.

Data hasil pretest menunjukkan bahwa hanya $52 \%$ anak yang mendapat nilai tinggi. Artinya 58\% yang lainnya hanya mendapat nilai rendah sampai sedang. Kemampuan fisik motorik kasar anak belum berekembang ditunjukkan dengan adanya anak 2 anak yang masih kesulitan dalam melakukan kegiatan pretest seperti merangkak dengan batasan waktu, melompat, berlari zig-zag dan meniti diatas papan titian. Dalam aktivitas merangkak kebanyakan anak hanya mendapat skor rendah karena anak belum mau berpacu dengan waktu yang ditentukan peneliti. Selain itu, pada aktivitas meloncat tepat dibidang sasaran ada beberapa anak yang hanya melangkah. Ketika seharusnya anak anak berlari zigzag peneliti juga menemukan anak yang hanya berjalan saja. Kegiatan terakhir berjalan diatas papan titian masih ditemukan beberapa anak yang belum mau melakukan kegiatan dengan alas an takut.

\section{Perkembangan Kemampuan Fisik Motorik Kasar Sesudah Penerapan Permainan Flower Circuit}

Penerapan permainan flower circuit dilakukan peneliti setelah mealakukan penilaian melalui kegiatan pretest. Permainan flower circuit oleh peneliti dijadikan treatment untuk merangsang dan mendukung perkembangan fisik motorik kasar anak. Setelah pemberian treatment barulah peneliti mengadakan penilaian yang kedua dalam kegiatan posttest. Kegiatan yang ada pada kegiatan posttest adalah kegiatan yang sama dengan kegiatan yang ada di pretest. Pretest dan posttest hanya dilakukan pada waktu yang berbeda.

Pada saat peneliti melakukan pengamatan pasca pretest di kelas B1 RA Al Huda Rejowinangun khususnya pada saat pembelajaran fisik motorik kasar, kemampuan anak sudah mulai berkembang lebih baik. Hal ini ditunjukkan dengan anak mulai dapat memperbaiki indikator yang belum tercapai pada saat pretest. Terlihat beberapa anak yang biasanya malas-malasan mengikuti kegiatan fisik motorik lebih antusias dari sebelumnya. Terdapat pula anak yang biasanya asik sendiri bermain dengan temannya ketika pembelajaran mulai terfokus dan mau mengikuti kegiatan fisik motorik dengan baik dan bersemangat.

Berdasarkan hasil posttest yang peneliti lakukan pada kelas B1 RA Al Huda Rejowinangun Trenggalek menunjukkan antusiasme anak yang sangat berbeda. Ketika pelaksanaan posttest semua anak menyelesaikan semua kegiatan. Anak anak terlihat lebih aktif bergerak dibandingkan pada saat pretest. Hal ini sesuai dengan pendapat yang dikemukakan oleh 
Kharisma (2015) bahwa permainan flower circuit dapat meningkatkan kemampuan fisik motorik anak kelompok B dan membuat anak lebih aktif bergerak. Maka dari itu dapat disimpulkan bahwa penerapan permainan flower circuit di kelas B1 RA Al Huda Rejowinangun berpengaruh pada tingkat keberhasilan perkembangan fisik motorik kasar anak.

\section{Efektivitas Permainan Flower Circuit Terhadap Perkembangan Fisik Motorik Anak Kelompok B}

Penerapan permainan pada pembelajaran fisik motorik kasar anak kelompok B merupakan cara yang dapat dilakukan agar pembelajarn menjadi lebih menarik. Sejalan dengan hal tersebut, menurut Santrock (2007:216-217) permainan adalah aktivitas menyenangkan yang dilakukan untuk bersenang-senang. Bermain adalah kegiatan yang sesuai dengan karakteristik anak usia dini yang pada dasarnya anak belajar melalui kegiatan bermain.

Penerapan permainan flower circuit di kelas B1 dapat meningkatkan kemampuan perkembangan fisik motorik kasar anak. Hal tersebut dibuktikan dengan hasil rata-rata yang diperoleh anak ketika posttest mengalami peningkatan dibandingkan ketika pretest. Selain itu peneliti juga melakukan penghitungan nilai posttest dengan menggunakan rumus paired samples test untuk mengetahui t hitung yang kemudian digunakan peneliti untuk menguji kebenaran hipotesis.

Permainan flower circuit yang diterapkan peneliti adalah permainan yang terdiri dari 4 pos. Permainan ini diadaptasi dari penelitian terdahulu oleh Kharisma (2015) dengan beberapa modifikasi pada setiap pos sertamodifikasi alat dan bahan yang digunakan. Kegiatan dimasingmasing pos merupakan kegiatan yang telah sesuai dengan kebutuhan di kelas B1 RA Al Huda Rejowinangun Trenggalek. Permainan flower circuit ini merukapan permainan yang telah mendapatkan validasi ahli dan dinyatakan sebagai permainan yang aman bagi anak, mudah untuk dilakukan dan menyenangkan bagi anak.

Hasil dari uji t yang telah dilakukan peneliti berupa t hitung menunjukkan bahwa ketika dibandingkan dengan $\mathrm{t}$ tabel menghasilkan jumlah yang lebih besar. Nilai t hitung sebesar 8.576 sedangkan nilai t tabel 2.069. karena nilai t hitung lebih besar dari pada nilai t tabel maka dapat disimpulkan bahwa Ha diterima dan Ho ditolak. Artinya, permainan flower circuit terbukti efektif terhadap perkembangan fisik motorik anak kelompok B RA Al Huda Rejowinangun Trenggalek.

\section{SIMPULAN DAN SARAN}

Penelitian ini menunjukkan hasil bahwa permainan flower circuit merupakan permainan yang efektif terhadap perkembangan fisik motorik kasar anak kelopok B di RA Al Huda 
Rejowinangun Trenggalek. Hal ini dibuktikan dengan adanya peningkatan skor sebelun dan sesudah diberikan perlakuan berupa permainan flower circuit.

Saran yang diberikan dalam penelitian ini antara lain untuk kepata TK dan guru diharapkan dapat memberikan kegiatan yang sesuai dengan karakteristik perkembangan anak, salah satunya melalui permainan flower circuit. bagi peneliti lain diharapkan dapat mengembangkan kedalam jenis penelitian dan desain yang baru.

\section{DAFTAR RUJUKAN}

Hurlock, E.B. 1978. Perkembangan Anak. Jakarta: Erlangga.

Kharisma,T.E.2015. Pengembangan Permainan Flower Circuit Pada Pembelajaran Fisik Motorik Kasar Untuk Anak Kelompok B Di Taman Kanak-Kanak Kecamatan GudoJombang.Malang: Universitas Negeri Malang.

Rahyubi, H. 2012. Teori-Teori Belajar dan Aplikasi Pembelajaran Motorik. Bandung: Nusa Media.

Santrock, J.W. 2007. Perkembangan Anak. Jakarta: Salemba Humanika.

Santrock, J.W. 2011. Perkembangan Anak. Jakarta: Salemba Humanika.

Sugiyono. 2016. Metode Penelitian Kuantitatif Kualitatif \& $R \& D$. Bandung: Alfabeta

Sujiono, B.2007. Metode Pengembangan Fisik (Edisi Revisi). Jakarta:

Universitas Terbuka. 